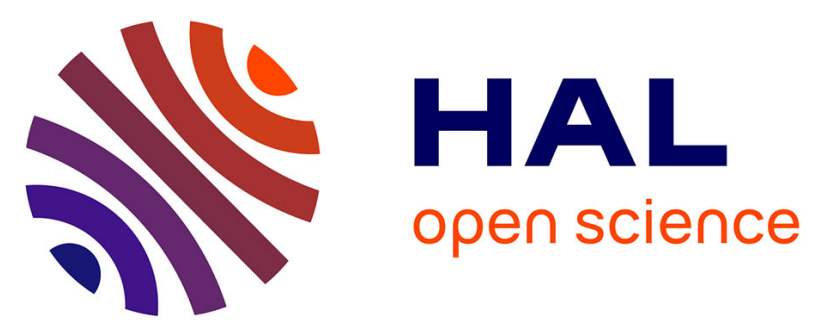

\title{
3D model related to the publication: Orliac M.J., Karadenizli L., Antoine P.-O., Sen S. 2015. Small suids (Mammalia, Artiodactyla) from the late Early Miocene of Turkey and a short overview of Early Miocene small suoids in the Old World.
}

Maeva Orliac, Levent Karadenizli, Pierre-Olivier Antoine, Sevket Sen

\section{To cite this version:}

Maeva Orliac, Levent Karadenizli, Pierre-Olivier Antoine, Sevket Sen. 3D model related to the publication: Orliac M.J., Karadenizli L., Antoine P.-O., Sen S. 2015. Small suids (Mammalia, Artiodactyla) from the late Early Miocene of Turkey and a short overview of Early Miocene small suoids in the Old World.. MorphoMuseum, 2015, 1 (2), 10.18563/m3.1.2.e4 . hal-01904996

\author{
HAL Id: hal-01904996 \\ https://hal.science/hal-01904996
}

Submitted on 25 Oct 2018

HAL is a multi-disciplinary open access archive for the deposit and dissemination of scientific research documents, whether they are published or not. The documents may come from teaching and research institutions in France or abroad, or from public or private research centers.
L'archive ouverte pluridisciplinaire HAL, est destinée au dépôt et à la diffusion de documents scientifiques de niveau recherche, publiés ou non, émanant des établissements d'enseignement et de recherche français ou étrangers, des laboratoires publics ou privés. 
-

3D model related to the publication: Orliac M.J., Karadenizli L., Antoine P.-O., Sen S. 2015. Small hyotheriine suids (Mammalia, Artiodactyla) from the late early Miocene of Turkey and a short overview of early Miocene small suoids in the Old World.

ORLIAC M.J. ${ }^{a^{*}}$, KARADENIZLI L. ${ }^{\text {, }}$, ANTOINE P.-O. ${ }^{\text {a }}$, Sen S ${ }^{\mathrm{c}}$.

a Institut des Sciences de l'Evolution de Montpellier, Université de Montpellier, CNRS, IRD, Cc 064; place Eugène Bataillon, 34095 Montpellier Cedex 5, France

${ }^{b}$ MTA Genel Müdürlüğü Jeoloji Etütleri Dairesi, Üniversiteler Mahallesi, Dumlupınar Bulvarı, TR-06800, Çankaya-Ankara, Turkey

${ }^{c}$ CR2P - Centre de recherches sur la paléobiodiversité et les Paléoenvironnements, UMR 7207 CNRS, UPMC, MNHN, 8 rue Buffon, 75005, Paris

*corresponding author: maeva.orliac@univ-montp2.fr

Abstract: This contribution contains the 3D model described and figured in the following publication: Orliac M.J., Karadenizli L., Antoine P.-O., Sen S. 2015. Small suids (Mammalia, Artiodactyla) from the late Early Miocene of Turkey and a short overview of Early Miocene small suoids in the Old World.

Key words: Suidae, Hyotheriinae, Çankiri-Çorum Basin, Central Anatolia, new species

Submitted 05.05.2015, Accepted 10.05.2015; doi: 10.18563/m3.1.2.e4

(C) Copyright Maeva Orliac Mai 2015

TECHNICAL AND SPECIMEN-RELATED PARAMETERS

\begin{tabular}{|l|l|}
\hline Specimen inventory number & SMT-1 \\
\hline Species & Nguruwe? galaticum \\
\hline Repository institution & Natural History Museum of Ankara, Turkey \\
\hline 3D data acquisition institution & Université de Montpellier, France \\
\hline 3D data acquisition method & X-ray $\mu$ CT \\
\hline 3D data acquisition facility model & In Vivo Mictotomograph SkyScan 1076 \\
\hline 3D data acquisition operator & R. Lebrun \\
\hline Voxel size of original dataset & 0.036 mm \\
\hline Author of derived 3D surface model & Maeva Orliac \\
\hline Model ID & M3\#16 SMT-1 \\
\hline & $\begin{array}{l}\text { The specimen corresponds to a fragment of the left upper cheek tooth } \\
\text { raw, bearing fragmentary M1-M3. }\end{array}$ \\
\hline
\end{tabular}

\section{METHODS}

Before restoration of the fragmentary cranium $n^{\circ}$ SMT-1, a portion of the left upper molar raw (broken appart) was scanned in order to visualize the morphology of the roots of the molars (Orliac et al., 2015: fig. 3). AVIZO 6.3 (Visualization Sciences Group) software was used to produce the 3D surface model. This 3D model is provided in .ply format, and as such can be opened with a wide range of freeware.

\section{ACKNOWLEDGEMENTS}

We are grateful to R. Lebrun for its help in data acquisition (CT scan). Data presented here were produced through the technical facilities of the MRI platform and of the labEx CeMEB.

\section{BIBLIOGRAPHY}

Orliac, M.J., Karadenizli L., Antoine P.-O., Sen, S. 2015. Small hyotheriine suids (Mammalia, Artiodactyla) from the late early Miocene of Turkey and a short overview of early Miocene small suoids in the Old World. Paleontologia electronica 18(2): 18.2.30A: 1-48 